\title{
FUNCIÓN ESTÉTICA Y SIGNIFICACIÓN HISTÓRICA DE LAS CAMPAÑAS PASTORAS EN EL FACUNDO
}

Sarmiento intenta en el Facundo ${ }^{1}$ la explicación de la tiranía por la geografía del país y por las costumbres que el medio ha desarrollado en el hombre español trasladado a estas tierras. Interpreta el momento histórico como una lucha entre la civilización y la barbarie, representada por el elemento social de las campañas pastoras que apoya a los caudillos. No discutiremos ahora las raíces de estas ideas ${ }^{2}$. Lo que nos interesa es ver que la pampa, el gaucho y ciertos rasgos de su vida primitiva figuran en el Facundo con una doble función: por una parte entran en la explicación racional de un hecho histórico-cultural, y por otra tienen una justificación estética dentro de la obra.

Para comprender su mundo imaginativo y sus preferencias literarias, quizás convenga recordar algunos de los fundamentos del romanticismo que le sirven de base teórica.

\section{LA ESTÉTICA ROMÁNTICA}

Sarmiento es un hombre formado en la ideología ilustrada del siglo xvin, que se adhiere con entusiasmo al nuevo ideal romántico, pero conserva ciertos rasgos de su antigua formación y evoluciona por su interés en el bien público hacia lo que su generación llama "socialismo" o "escuela progresista"3.

1 Se cita el Facundo ( $F$ y número de página) por la edición de Alberto Palcos, Universidad de La Plata, La Plata, 1938, y los demás libros por la edición original de las Obras de D.F. Sarmiento publicadas con los auspicios del gobierno argentino en Santiago de Chile y en Buenos Aires, desde $188_{5}$ (52 tomos y un índice general). Llamo la atención sobre el hecho de que algunos tomos más vendidos se reimprimieron hasta dos veces con diferente paginación, y con adiciones en ciertos casos. El número romano indica el tomo y el arábigo la página; la ortografía ha sido modernizada.

2 Cf. mi artículo "Las ideas de Sarmiento antes de la publicación del Facundo", Fil, 5 (1959), 199-210, y la bibliografía citada allí.

3 Véase la polémica sobre romanticismo que sostuvo Sarmiento con motivo de un artículo aparecido en el Semanario de Santiago en Chile en $18_{42}$ (especialmente I, 304-305 y 309). También A. W. Bunkley, The life of Sarmiento, Princeton, 1952, cap. xvi. 
Del romanticismo le atrae la búsqueda de lo original y propio, y también la valoración de lo espontáneo y natural, un gusto por lo grandioso fuera de las medidas comunes, un afán de moverse entre las oposiciones y los contrastes violentos ${ }^{4}$.

Lo típico de cada país servirá para explicar su historia, según expone en la introducción del Facundo al referirse a la biografía de Bolívar vista con ojos europeos ${ }^{5}$; y juzga que le corresponde la gloria de haber sido el primero en realizar tal ideal historiográfico para la América hispánica ${ }^{6}$.

Pero además, sólo lo original y propio llevará al escritor americano a la realización de obras maestras. En este camino, en teoría y práctica, se le había adelantado Echeverría, maestro de su generación ${ }^{7}$. Sarmiento lo sigue e insiste en sus posibilidades creadoras:

Si un destello de literatura nacional puede brillar momentáneamente en las nuevas sociedades americanas, es el que resultará de la descripción de las grandiosas escenas naturales, y sobre todo, de la lucha entre la civilización europea y la barbarie indígena, entre la inteligencia y la materia: lucha imponente en América, y que da lugar a escenas tan peculiares, tan características y tan fuera del círculo de ideas en que se ha educado el espíritu europeo... $(F, 47)$.

4 Para estos aspectos de la estética romántica y sus antecedentes, que se remontan al siglo xviI, véase Paul Van Tieghem, Le préromantisme, Paris, 1948, t. 1, pp. 21-64, y Le romantisme dans la littérature européenne, Paris, 1948.

5 "Sin estos antecedentes, nadie comprenderá a Facundo Quiroga, como nadie, a mi juicio, ha comprendido todavía al inmortal Bolívar, por la incompetencia de sus biógrafos. . ; en esta biografía, como en todas las otras que de él se han escrito, he visto al general europeo... pero no he visto al caudillo americano, al jefe de un levantamiento de masas; veo el remedo de la Europa, y nada que me revele la América. Colombia tiene llanos, vida pastoril, vida bárbara americana pura, y de ahí partió el gran Bolívar: de aquel barro hizo su glorioso edificio. ¿Cómo es, pues, que su biografía lo asemeja a cualquier general europeo de esclarecidas prendas?... El dranıa de Bolívar se compone, pues, de otros elementos de los que hasta hoy conocemos; es preciso poner antes las decoraciones y los trajes americanos para mostrar enseguida el personaje. Bolívar, el verdadero Bolívar, no lo conoce aún el mundo; y es muy probable que cuando lo traduzcan a su idioma natal, aparezca más sorprendente y más grande aún" $(F, 20-21)$.

6 Véanse la carta a su nieto $\left(F, 45^{2-453}\right)$, las opiniones de los extranjeros de Montevideo que Juan Cruz Varela le transmitió y otras que consigna con motivo de la traducción italiana del Facundo (XLVI, 320 ss.), además de las reseñas aparecidas en $E l$ Mercurio de Valparaíso y El Progreso de Santiago de Chile $(F, 323$ y 326$)$.

7 Para el ideario de Echeverría véanse sus trabajos "Forma y fondo de las obras de imaginación" y "Notas del autor de los Consuelos" en Obras completas, Buenos Aires, 1871 , tomos 5 y 3. Para los orígenes del romanticismo en el Plata, Ricardo Rojas, La literatura argentina, t. 3, "Los Proscriptos", Buenos Aires, 1920, y Pedro Henríquez Ureña, Literary currents in Hispanic America, Cambridge, Mass., 1946, pp. 116 ss. 
Más tarde, en los Viajes, se incluye con otros de sus amigos dentro de una breve reseña de lo que han logrado en la expresión de sí mismos, con un modo suelto, espontáneo, en el que el orgullo por la obra realizada está velado con visión indulgente y humorística que transmite el lenguaje conversacional empleado:

Echeverría describiendo las escenas de la pampa, Maldonado imitando el llano lenguaje, lleno de imágenes campestres del cantor, ¡qué diablos! por qué no he de decirlo, yo, intentando describir en Quiroga la vida, los instintos del pastor argentino, y Rugendas, pintando con verdad las costumbres americanas: he aquí los comienzos de aquella literatura fantástica, homérica, de la vida bárbara del gaucho... (V, 6i $)$.

La búsqueda de lo espontáneo en el romanticismo abarca tanto la actitud del escritor que revela su yo libremente, como la renovación de la técnica literaria (lenguaje, metáforas, rebelión contra las reglas, mezcla de géneros) y la aparición de nuevos asuntos (escenarios naturales, paisajes selváticos, personajes ingenuos, primitivos y violentos que no enmascaran sus reacciones con la capa de la cortesía).

Y aquí volvemos a ver con respecto a Sarmiento el mismo interés reflejado en dos planos. Porque lo natural será estéticamente más valioso para el artista, y el historiador encontrará, en los personajes ingenuos, figuras que revelen más claramente las fuerzas sociales en pugna y sirvan mejor para la demostración de su tesis que aquellos que han aprendido a ocultar su verdadero ser bajo el artificio. Por eso elige a Quiroga y no a Rosas como protagonista de su obra e insiste constantemente en que todo es impulso primitivo, fuerza ciega en uno, mientras en el otro predomina el cálculo frío.

Facundo... es el tipo más ingenuo del carácter de la guerra civil de la República Argentina; es la figura más americana que la revolución presenta... $(F, 19)$.

...la expresión más franca y candorosa de una de las fuerzas que han luchado con diversos nombres durante treinta años $\left(F, 25^{1}\right)$.

Pero Facundo, en relación con la fisonomía de la naturaleza grandiosamente salvaje que prevalece en la inmensa extensión de la República Argentina; Facundo, expresión fiel de una manera de ser de un pueblo, de sus preocupaciones e instintos; Facundo, en fin, siendo lo que fue, no por un accidente de su carácter, sino por antecedentes inevitables y ajenos de su voluntad, es el personaje histórico más singular, más notable, que puede presentarse a la contemplación de los hombres que comprenden que un caudillo que encabeza un gran movimiento social no es más que el espejo en que se reflejan en dimensiones colosales las creencias, las ne- 
cesidades, preocupaciones y hábitos de una nación en una época dada de su historia $(F, 20)^{8}$.

Los últimos párrafos citados muestran también el gusto por lo grandioso y lo que se aparta de los patrones comunes (en el ser humano elegido y en su entorno), una visión agigantada de tensiones violentas y contrastes extremos.

\section{LA PAMPA}

Las grandes llanuras aparecen constantemente en el Facundo para explicar el caudillismo. La escasa población concentrada en ciudades aisladas una de otra por el desierto, la masa pastora diseminada por el campo, lejos de centros urbanos que le proporcionen cultura religiosa, política y social (escuela, iglesia, teatro, industria, comercio, etc.), favorecen la barbarie. Si analizamos el capítulo primero de la parte primera vemos que predominan, sobre la descripción pintoresca o de resonancia estético-emocional en el paisaje, aquellos rasgos de información geográfica que dan en forma sintética los datos necesarios para la comprensión del fenómeno histórico.

A veces la nota puede ser simplemente explicativa de los resultados de la extensión y falta de densidad demográfica ("El mal que aqueja a la República Argentina es la extensión...", "la pampa es un malísimo conductor para llevarla [la civilización] y distribuirla en las provincias. ..", $F$, 30, 33$)^{9}$.

$\mathrm{Su}$ inmensidad sirve para explicar también ciertos rasgos del hombre que vive en ella (libertad, rechazo de la sujeción, inseguridad de la existencia que desarrolla el orgullo, la apreciación del valor personal, el estoicismo ante la muerte). Estos aspectos interesan a Sarmiento por su repercusión en la política del país (constitución de la montonera, elevación de los caudillos, formas sanguinarias de gobierno), pero también porque se inscriben en sus propias preferencias estéticas de valoración romántica de los modos primitivos, espontáneos, imaginativos. Así se complace en destacar que el gaucho posee una capacidad poética natural nacida del contacto

8 Sarmiento inicia el cap. $\mathrm{v}$ (parte II, cap. $1^{\circ}$ en otras ediciones), dedicado a la vida de Quiroga, con un texto de Alix: "L'homme de la nature et qui n'a pas encore appris à contenir ou déguiser ses passions. ..", y lo vuelve a citar en la p. 10o, destacando la aplicación a su héroe.

9 Lo intelectual y objetivo casi nunca aparece en el Facundo en estado puro. Basta recordar la continuación de la frase citada: "el desierto la rodea por todas partes y se le insinúa en las entrañas" $(F, 30)$, o el gusto por las comparaciones orientales y la cita de Volney $(F, 34)$ en el mismo capítulo. Para el tratamiento del paisaje en nuestro autor, cf. Francisca Chica Salas, "Sarmiento y el paisaje", Bol. del Inst. de Cultura Lat.-Americano de la Facultad de Filosofía y Letras de Buenos Aires, 2 (1938), núm. 2. 
con un ámbito grandioso y vago que favorece las creaciones de la fantasía $(F, 49)$.

En el mismo capítulo segundo expone su credo americanista en literatura: la tierra enemiga de la civilización es fuente de originalidad para el escritor que se inspira en ella $(F, 47)$.

El paisaje de América había sido descubierto por el supercivilizado europeo, que encontraba en él dos notas fundamentales del romanticismo: lo selvático, lo no hollado, por oposición a lo artificioso; lo infinito, por oposición a lo mesurado y abarcable ${ }^{10}$. Sarmiento sintió poderosamente la grandeza del nuevo continente, y aún le duraba el entusiasmo en 1887 , cuando escribía a Paul Groussac para animarlo a traducir al francés los artículos de José Martí:

Ahora pídole su concurso para llevar a todas partes con el francés, que es la lengua universal del espíritu humano, la palabra americana, genuina, sintiendo a selva virgen, a cascada del Niágara, a cadena de los Andes, a corrientes de aguas como el Mississipi o el Plata, a Pampa en fin que deja ver la curvatura de la tierra sin obstáculo humano que oponerle, aunque fuera el puente de Brooklyn, o alguna pirámide tlascalteca o de quien sea, que deja enanas las del Egipto (XLVI, 174) ${ }^{11}$.

La pampa que entra en el Facundo en función de una argumentación morfogenética, figura también por sus propios valores literarios. Su autor, como todos lo saben, no la conocía entonces y trató de describirla vividamente por informaciones recogidas de distintas fuentes ${ }^{12}$. Más tarde, en La campaña en el Ejército Grande, recor-

10 Compárese con este texto de El Artista, periódico español de 1835 citado por G. Díaz Plaja, Introducción al estudio del romanticismo español, 2 a ed., Madrid, 1942, p. 115: los románticos prefieren “...una selva virgen del Nuevo Mundo, con todo su desorden, su aspereza y su imponente majestuosidad, con sus cataratas, despeñaderos y ríos tormentosos, llenos de caimanes, a un parque con sus calles tiradas a cordel y tapizadas de blanca y menuda arena, con los árboles peinados y recortados según el capricho del jardinero y sus piélagos artificiales de agua espesa y verdosa, en que sólo nadan peces de colores, sapos y sanguijuelas". Y cf. también el prefacio de V. Hugo (1826) a Odes et ballades.

11 Otros textos del Facundo muestran el mismo deseo de realzar lo extraordinario del paisaje americano: "Al norte, confundiéndose con el Chaco, un espeso bosque cubre con su impenetrable ramaje extensiones que llamariamos inauditas, si en formas colosales hubiese nada inaudito en toda la extensión de la América..."; "Pero estos inmensos canales excavados por la solícita mano de la naturaleza. .."; “. . . se dan cita de todos los rumbos del horizonte. .." $(F, 31)$; "De todos estos ríos que debieran llevar la civilización, el poder y la riqueza hasta las profundidades más recónditas del continente..." $\left(F, 3^{2}\right)$.

12 "Sabe usted que no he cruzado la pampa hasta Buenos Aires, habiendo obtenido la descripción de ella de los arrieros sanjuaninos que la atraviesan todos los años, de los poetas como Echeverría, y de los militares de la guerra civil. Quiérola sin embargo y la miro como cosa mía. Imaginomela yerma en el invierno, calva y polvorosa en el verano, interrumpida su desnudez por bandas de cardales y de viznagas" (V, 302). 
dará el momento del contacto directo con su imaginada criatura y la emoción de ese primer encuentro. El pasaje revela con qué fibras tensas estaba pre-dispuesto a sentirla y lo que la llanura representaba para él.

iA caballo, en la orilla del Paraná, viendo desplegarse ante mis ojos en ondulaciones suaves pero infinitas hasta perderse en el horizonte, la Pampa que había descrito en el Facundo, sentida por intuición, pues la veía por la primera vez de mi vida! (XIV, 159) .

Si nos detenemos a considerar sus descripciones de la llanura nos encontramos sólo con unos pocos rasgos caracterizadores: extensión infinita, vegetación desprovista de árboles y con hierbas naturales (cardales, viznagas, pajonales, hierbas amargas, pastos) ${ }^{13}$, horizonte a menudo impreciso, cielo a veces tormentoso y rasgado por los relámpagos. Entre estos rasgos predominan dos: la nota del espacio sin límites y la de la vida peligrosa; como el mismo Sarmiento resume en otra ocasión: lo grande y lo violento ("Sólo la inmensidad de la Pampa, y el estampido del rayo impresionan, con la idea de lo grande el uno, y de lo violento el otro", XLVI, 275).

Suelo llano, monótono, sin elevaciones o con ondulaciones suaves, cielo en íntimo contacto con la tierra - lo cual acentúa la sensación de lo infinito-, línea curva del horizonte, unas veces nítida, la mayoría borrada por nieblas - lo cual aumenta la incertidumbre en la fusión de ambos planos. "Infinito", "inmenso", "grandioso" son adjetivos que afloran a cada paso ${ }^{14}$. En el capítulo primero del $F a$ cundo, la construcción anafórica martillea con la repetición del mismo epíteto:

Allí la inmensidad por todas partes: inmensa la llanura, inmensos los bosques, inmensos los ríos, el horizonte siempre incierto, siempre confundiéndose con la tierra, entre celajes y vapores tenues, que no dejan, en la lejana perspectiva, señalar el punto en que el mundo acaba y principia el cielo $\left(F, 3^{\circ}\right)$.

13 En el Facundo, además de indicar los cambios de Norte a Sur en la vegetación de la Argentina, anota observaciones vagas acerca de la pampa misma: "despejada y monótona faz" $(F, 33)$, "su lisa y velluda frente" $(F, 31)$, "el más ligero susurro del viento que agita las hierbas secas" $(F$, 30) y "al salir de la luna tranquila y resplandeciente por entre las hierbas de la tierra" $(F, 34)$. En otras obras aparecen "hierbas amargas" (XLVI, 321), "pastos y matorrales" (I, 4), "cardales y viznagas", "los pajonales del desierto" (V, 302 y 41). En La campaña en el Ejército Grande muestra un interés mayor en los detalles pintorescos o técnicos, porque el contacto con el paisaje es ahora directo, y por la indole misma de la obra (XIV, 211, 175, 176, 206, 207, 216).

14 Véase la cita atribuida a Head $(F, 29)$-que pertenece en realidad a Humboldt, Tableaux de la nature..., t. 1, Paris, 1808, p. 21-, y todo el capítulo primero. 
También la imagen corriente del mar, lugar común en las descripciones europeas de las llanuras, tópico en los viajeros que visitaban el Río de la Plata ${ }^{15}$, le ayuda a traducir la infinitud terrestre. El paisaje se vitaliza y se anima en Sarmiento; por eso hasta un enemigo como Pedro de Angelis podía sentirlo vivir en oleadas que acentúan su comparación con el mar ("... esto se mueve, es la Pampa; el pasto hace ondas agitado por el aire, se siente el olor de las hierbas amargas. .."16).

Pero sobre todo la llanura se dinamiza por la capacidad que tiene en potencia para que en ella se despliegue la dinámica del gaucho, pronto a disparar su potro libremente en una carrera sin obstáculos. La pampa vive por sí, pero especialmente por el hombre que la habita, y su tamaño sin límites, aunque es angustia y soledad, también es libertad y afirmación de hombría.

Los gauchos que formaban el valiente regimiento de granaderos a caballo, tendían con desasosiego sus miradas por este horizonte estrecho y limitado por todas partes de cerros, echando menos aquellas inmensas llanuras de su tierra, donde el cielo está pegado a la superficie, donde el sol sale y se entra por entre los pastos y matorrales, y donde no hay barrera ni obstáculo insuperables para el jinete que monta un buen caballo... (I, 3-4).

La nota de lo violento y lo dramático suele nacer de ese cielo inmenso donde pueden desatarse en un instante la tormenta y el rayo, con sus estallidos, sus contrastes de luz y sombra, su amenaza de muerte:

¿Ni cómo ha de dejar de serlo [poeta] cuando en medio de una tarde serena y apacible, una nube torva y negra se levanta sin saber de dónde, se extiende sobre el cielo mientras se cruzan dos palabras, y de repente el estampido del trueno anuncia la tormen-

15 “. . hasta que al fin al sud triunfa la Pampa, y ostenta su lisa y velluda frente, infinita, sin límite conocido, sin accidente notable: es la imagen del mar en la tierra..." $(F, 31)$. Véase también la cita de Humboldt $(F, 47)$, tomada de la obra citada, t. 1, p. 8, y como ejemplo de notas de viajes: "Mais peutêtre aussi cette Pampe sévère, glacée en hiver, brûlante en été, solennelle dans son immensité comme l'Océan, a-t-elle son charme pour le gaucho; peut être est-elle en harmonie avec le caractère de cet homme fier et indépendant, dont la vie tout entière est employée à parcourir au galop, dans tout les sens, ces vastes solitudes" (Th. Pavie, "Les Indiens de la Pampa", RDM, 1935, 1, 141-142).

16 Sarmiento cita estas palabras de Pedro de Angelis a Guido Spano, diciendo que alguien se las comunicó. Sean o no verdaderas, revelan el efecto que podía despertar el libro en los contemporáneos (XLVI, 321). En el mismo artículo sobre la traducción italiana del Facundo, Sarmiento lo llama "el Génesis de la Pampa", y dice que ésta "es tan poética hoy en la tierra, como las montañas de la Escocia diseñadas por Walter Scott" gracias a su obra (XLVI, $322-323)$. 
ta que deja frío al viajero, y reteniendo el aliento por temor de atraerse un rayo de dos mil que caen en torno suyo? La oscuridad se sucede después a la luz; la muerte está por todas partes; un poder terrible, incontrastable le ha hecho en un momento reconcentrarse en sí mismo, y sentir su nada en medio de aquella naturaleza irritada; sentir a Dios, por decirlo de una vez, en la aterrante magnificencia de sus obras... Masas de tinieblas que anublan el día, masas de luz lívida, temblorosa, que ilumina un instante las tinieblas, y muestra la Pampa a distancias infinitas, cruzándola vivamente el rayo, en fin, símbolo del poder $\left(F, 49^{-5}\right)$.

También las acciones del hombre a caballo, la amenaza del malón, de la montonera, o el ataque de tigres y víboras acentúan el dramatismo $(F, 30)$; la infinitud y la violencia así conjugadas crean el ámbito propicio a las sugerencias poéticas:

¿Qué impresiones ha de dejar en el habitante de la República Argentina el simple acto de clavar los ojos en el horizonte, y ver... no ver nada; porque cuanto más hunde los ojos en aquel horizonte incierto, vaporoso, indefinido, más se le aleja, más lo fascina, lo confunde, y lo sume en la contemplación y la duda? ¿Dónde termina aquel mundo que quiere en vano penetrar? ¡No lo sabe! ¿Qué hay más allá de lo que ve? La soledad, el peligro, el salvaje, la muerte!!! $(F, 49)$.

\section{El PAISAJE COMO RESONADOR}

La naturaleza americana tiene a menudo, en Sarmiento, la función de resonador de un personaje o una acción, que así adquiere notas de misterio, de intensidad salvaje, de grandeza áspera o solemne.

La vida de El general Fray Félix Aldao se abre con una escena que tiene por fondo las cumbres colosales de los Andes, el río que se desliza silenciosamente, la quebrada profunda. Entonces, la matanza en que Aldao revela sus instintos sanguinarios, proyectada en un camino de crímenes futuros, se agranda con la perspectiva de la naturaleza severa e imponente ${ }^{\mathbf{1}}$.

Al final de su carrera política Sarmiento escribe una página inolvidable en la que sintetiza el sentido de su vida ${ }^{18}$. No es extremo en la propia glorificación; hasta puede ser modesto en la apreciación de sus valores ("he escrito algo bueno entre mucho indiferente"); pero como tenía conciencia de su papel en la historia de la Argentina y de América, sabe dar a su perfil las líneas definitivas de la

17 El pasaje asombra por su modernidad: está enfocado con un primer plano de sables que se alzan y se entrechocan, alrededor de una figura extraña vestida de blanco, semejante a un fantasma (VII, 241).

18 Véase en Pedro Henríquez Ureña y Jorge Luis Borges, Antología clá. sica de la literatura argentina, Buenos Aires, s. f., pp. 100-101. 
estatua, por ejemplo cuando resume su labor de educador: “...y columnas miliarias en los edificios de escuelas marcarán en América la ruta que seguí". La página se inicia, precisamente, con la mención de los Andes como punto de partida de un camino de experiencias que abarca casi todo el mundo civilizado, y aquí lo que queda realzado con sus cimas nevadas es un periplo de vida ejemplar y laboriosa, dedicada a servir a los hombres.

En el Facundo el paisaje actúa como resonador de la lucha entre civilización y barbarie, y la agiganta con las sugerencias de la aspereza salvaje, del misterio, la inmensidad, el sentimiento de las limitaciones humanas, los contrastes. Quiroga está en relación con su entorno, y el suelo, aun en aquellos parajes en que parece explicarlo objetivamente, lo carga de sobretonos emocionales e imaginativos: "...Facundo en relación con la fisonomía de la naturaleza grandiosamente salvaje que prevalece en la inmensa extensión de la República Argentina..." $(F, 20)$.

Si los contrastes de la llanura y las ciudades no bastan para concretar la oposición de civilización y barbarie, los bosques de América virgen vendrán a reforzarla ${ }^{19}$.

[El Dr. Francia, en el Paraguay,] abre una nueva página en la historia de las aberraciones del espíritu humano: encierra a un pueblo en sus límites de bosques primitivos, y borrando las sendas que conducen a esta China recóndita, se oculta y esconde durante treima años su presa en las profundidades del continente americano, y sin dejarla lanzar un solo grito, hasta que muerto él mismo por la edad y la quieta fatiga de estar inmóvil pisando un pueblo sumiso, éste puede al fin, con voz extenuada y apenas inteligible, decir a los que vagan por sus inmediaciones: „Vivo aún! pero cuánto he sufrido... $(F, 13)$.

Los bosques impenetrables, la tierra que atrapa y encierra como un laberinto, ponen su nota de misterio, de infınitud y primitivismo para ahondar la expresión de la muerte y el vacío que crea a su alrededor la tiranía, en esta página de impresionante poder verbal.

La pampa que explica, en parte, la existencia del caudillismo,

19 '....un mundo nuevo en política, una lucha ingenua, franca y primitiva entre los últimos progresos del espíritu humano y los rudimentos de la vida salvaje, entre las ciudades populosas y los bosques sombríos" $(F, 12)$. Humboldt, que vio en Venezuela el contacto de las zonas cultivadas con los llanos ganaderos como una causa de retroceso, también expresó la oposición por medio de las selvas, en un texto que quizá influyó en Sarmiento: "la barbarie y la civilización, las selvas impenetrables y los terrenos cultivados, se tocan y delimitan" (Viaje a las regiones equinoxiales del Nuevo Continente, hecho en 1799, I800, I801, I802, I803 y 1804, por A. de Humboldt y A. Bonpland, redactado por A. DE Humboldt, ed. Caracas, 1941, t. 2, pp. 293-294. (Este dato me ha sido facilitado por el profesor Salvador Raúl Vicini, en su artículo "Humboldt y Sarmiento" de próxima aparición en Fil. 
que interesa literariamente por ofrecer una fuente de creación original, que sirve de resonador en ciertos momentos de la obra, se convierte también en un símbolo de la barbarie junto con otros elementos asociados a la vida pastoril ("bastó que agitase la Pampa para echar por tierra su edificio basado sobre arena”, $F, 296$; “¡Bárbaro! jes la ciudad que trata de salvarse, de no ser convertida en Pampa, si abandona la educación que la liga al mundo civilizado!", $F, 278)^{20}$. La palabra acaba por ser un sinónimo más concreto de bárbaro y barbarie, y cumple su ciclo soldándose en expresiones como: hijo de la pampa, gaucho (o salvaje) de la pampar.

\section{EL GAUCHO Y SUS FORMAS DE VIDA}

En la primera parte del Facundo, Sarmiento expone el influjo de la geografía en los descendientes de los españoles trasladados a playas americanas. El ganado, procreado naturalmente, les proporciona los medios de subsistencia con escaso trabajo, y desarrolla la incuria por la ociosidad y el aislamiento de los centros culturales ${ }^{22}$. El habitante de la pampa forma la masa inculta que sostiene a los caudillos: en la antinomia "civilización y barbarie", el último término está representado por la campaña y el gaucho, en oposición a las ciudades.

Rosas, Quiroga y los demás caudillos, que se apoyan en el elemento popular de las campañas, son ellos mismos el resultado de una educación impregnada de fuerzas barbarizadoras, y a su vez los instrumentos de su difusión por la persecución constante de la cultura, por la ostentación propia de los aspectos rústicos, por la protección de lo gaucho y su elevación a sistema de gobierno. Sarmiento presenta a Facundo Quiroga ${ }^{23}$ como el tipo acabado de gaucho malo elevado por los vaivenes de la política a comandante de campaña y más tarde a dueño indiscutido del interior andino. De Ro$\operatorname{sas}^{24}$ destaca la educación gaucha, la vida en la campaña durante la mayor parte de su existencia, su destreza y vigor físico, su gobierno calcado de la organización de la estancia con irónico paralelo entre los pueblos sometidos y el ganado:

${ }^{20}$ Cf. también: “... si el espíritu de la Pampa no hubiese soplado sobre ella..." $(F, 32)$. Y en los Viajes: "Tu porvenir está asegurado; el incendio de los pajonales del desierto ha pasado sobre tu superficie; la hierba que nazca será fresca y blanda para todos" ( $\mathrm{V}, 41)$, donde aparece el "desierto" con igual función que la pampa.

${ }^{21}$ Véase $F, 294,225,286$.

22 Véanse los cap. I-III del Facundo y mi art. cit., especialmente p. 209.

${ }^{23}$ Véase $F, 170,152,189$ y 194 .

${ }^{24}$ Para la explicación del carácter de Rosas por la educación en la campaña, unida a la herencia hispánica, véase el cap. xrv, especialmente pp. 261264. En cuanto a la comparación de su gobierno con el del ganado, las observaciones del mismo Rosas la favorecían (nota 14 de mi artículo ya citado). 
... las fiestas de las parroquias son una imitación de la hierra del ganado, a que acuden todos los vecinos; la cinta colorada que clava a cada hombre, mujer o niño es la marca con que el propietario reconoce su ganado; el degüello, a cuchillo, erigido en medio de ejecución pública, viene de la costumbre de degollar las reses que tiene todo hombre en la campaña; la prisión sucesiva de centenares de ciudadanos sin motivo conocido y por años enteros, es el rodeo con que se dociliza el ganado, encerrándolo diariamente en el corral; los azotes por las calles, la mazorca, las matanzas ordenadas son otros tantos medios de domar a la ciudad, dejarla al fin como el ganado más manso y ordenado que se conoce $(F, 263$ 264).

El mismo tema de la vida campesina muestra otros valores, considerado desde el ángulo literario. Ya vimos antes que los románticos buscaban en la llanura y su habitante una fuente de inspiración original, y que Sarmiento lo expuso así varias veces. En su primer libro reunió una serie de retratos del rastreador, el baqueano, el gaucho malo y el cantor ${ }^{25}$, cuya inclusión justificó por una necesidad interna de la obra, pues eran manifestaciones sociales que explicaban la historia del caudillismo.

Valentín Alsina ${ }^{26}$-lector contemporáneo del Facundo- le objetó que la elección de tipos significativos había sido arbitraria, y estaba condicionada por su sistema de ideas, el cual lo llevaba a erigir en "clases" ciertos rasgos que sólo eran "excepciones y rarezas". No nos interesa ahora discutir la adecuación de sus observaciones a la realidad: en cambio conviene destacar que si el baqueano, el gaucho malo, el rastreador son elementos "necesarios" para su demostración histórico-cultural, el cantor entra en el libro por la sensibilidad romántica hacia la poesía popular y por el gusto de relacionar el ámbito infinito de la llanura con los anhelos vagos, con el despertar de la capacidad poética, imaginativa y religiosa.

Todas las descripciones iniciales - justificadas o no por su explicación social- tienen una razón de ser literaria: la creación de tipos originales y pintorescos. A Sarmiento le gustaba compararse con F. Cooper, W. Scott y Volney ${ }^{27}$, y se enorgullecía de haber dado vida a formas humanas desconocidas por el europeo, con un sabor

25 "Aún podría añadir a estos tipos originales muchos otros igualmente curiosos, igualmente locales, si tuviesen como los anteriores la peculiaridad de revelar las costumbres nacionales, sin lo cual es imposible comprender nuestros personajes políticos, ni el carácter primordial y americano de la sangrienta lucha que despedaza a la República Argentina. Andando esta historia, el lector va a descubrir por sí solo dónde se encuentra el Rastreador, el Baqueano, el Gaucho Malo o el Cantor" $(F, 63)$. Más tarde recuerda al Cantor con motivo de La Madrid, y al capataz de carretas con respecto al Boyero $(F, 144,195-196)$.

$2{ }^{26}$ Pueden consultarse sus notas en $F, 365-366$.

27 Véase XLVI, 306 y 323. 
peculiar americano. Es indudable que era un escritor de condiciones excepcionales para el retrato dinámico, en el que la silueta dibujada destaca, con el movimiento, sus rasgos esenciales.

El gaucho llega a la hierra al paso lento y mesurado de su mejor parejero, que detiene a distancia apartada; y para gozar mejor del espectáculo, cruza la pierna sobre el pescuezo del caballo. Si el entusiasmo lo anima, desciende lentamente del caballo, desarrolla su lazo y lo arroja sobre un toro que pasa con la velocidad del rayo a cuarenta pasos de distancia: lo ha cogido de una uña, que era lo que se proponía, y vuelve tranquilo a enrollar su cuerda $(F, 45-46)^{28}$.

La escena cierra el capítulo primero, donde ha expuesto la destreza física del gaucho y su incuria, y resume en la ostentación de una hazaña casi increíble pero gratuita un valor que no se canaliza en obras de progreso para el país. Además, sabe captar con finura de matiz la calidad peculiar de ese orgullo por la habilidad personal, que se muestra con aparente desgano (volviendo a la nativa indolencia) y con sobriedad y economía de gestos ${ }^{29}$.

El gaucho, como la pampa, explica la barbarie y acaba por convertirse en elemento simbólico. Hay matices en la presentación de esta función significativa. A veces muestra un hecho histórico o anecdótico sin aparente importancia, y lo ilumina para revelar el sentido profundo que lo eleva a la condición de símbolo de un proceso social. Otras, el gaucho y los objetos ligados a su vida son fuentes que alimentan el mundo de la fantasía, la expresión metafórica del escritor. Como en el caso de la llanura, la palabra gaucho acaba por convertirse en otro modo de nombrar a Rosas y a Quiroga desta-

28 R. Moglia reproduce en su edición del Facundo, Buenos Aires, 1955, p. 299, una nota manuscrita de Mitre en el ejemplar que le pertenecía: "No hay lazo que tenga $4^{\circ}$ pasos de extensión, ni se puede hacer tiro de lazo a esta distancia..." La exageración de Sarmiento y su falta de adecuación con la realidad no aminoran el valor expresivo de esta página.

29 Igual serenidad y sangre fría muestra el cantor sorprendido por la policía: "El cantor oyó la grita sin turbarse: viósele de improviso sobre el caballo, y echando una mirada escudriñadora sobre el círculo de soldados con las tercerolas preparadas, vuelve el caballo hacia la barranca, le pone el poncho en los ojos y clávale las espuelas. Algunos instantes después se veía salir de las profundidades del Paraná, el caballo sin freno, a fin de que nadase con más libertad, y el cantor tomado de la cola, volviendo la cara quietamente, cual si fuera en un bote de ocho remos, hacia la escena que dejaba en la barranca" $(F, 62)$. En otro fragmento de los Viajes, libre de intereses significativos de un carácter, se destaca el despliegue de la maestría en la captación de lo puramente visual y cinético, por lo que tiene de pintoresco: "Paréceme ver al viejo Chano... acercándose... al tranco majestuoso y pausado del caballo del gaucho, estirado el cuello del corcel sin gracia, mientras que el jinete, sentándose sobre las vértebras, describe con su espalda una curva que avanza hacia adelante, la cabeza inclinada para romper el viento y dejar al cuerpo toda su flexibilidad" (V, 61). 
cando su grosera brutalidad, y también en un simple sinónimo de "barbarie". Junto a ella aparecen los términos "indio" y "salvaje", las frases "gaucho de la pampa" o "salvaje de la pampa", y la variante dedicada a Rosas, "estanciero de Buenos Aires"

En ciertos momentos rejuvenece las frases estereotipadas con nuevas asociaciones, por ejemplo, con el insólito emparejamiento "gaucho gobernador" ( $F, 264)$, o con un desarrollo de las notas de tosquedad y rusticidad barbarizadora que culmina con la alusión al odiado color de los federales y su sangrienta resonancia: “... esa ingrata y torpe Buenos Aires, desde donde le viene hoy el movimiento barbarizador impreso por el gaucho de la marca colorada" $(F, 226)$. Rosas, con simplificación conscientemente realizada por el autor, queda rebajado a la categoría de burdo bandido, marcador y degollador de hombres como de ganado, en un estilo de eficacia activa, directa y concretizadora.

\section{Otros elementos: el caballo}

Sarmiento explica el papel fundamental que desempeña el caba11 o en la vida del gaucho ${ }^{31}$ desde su infancia hasta su madurez -tanto en el trabajo como en las diversiones-, la pericia casi mítica que alcanza en su manejo, la función que ejerce en su escala de valores con respecto a los demás hombres. Busca paralelos con la vida de otros pueblos de llanura (tártaros, árabes, bárbaros invasores del Imperio romano) para afianzar su tesis de la influencia del suelo en las costumbres y de éstas en la historia de los pueblos, pero además dichas comparaciones le atraen por el prestigio del color local y la lejanía que las carga de valor poético en la época romántica ${ }^{32}$.

Con las notas de lo exótico, alterna en él la observación concreta de la realidad más inmediata, más próxima a su experiencia y a la de sus lectores, en una visión unas veces humorística y otras trágica y estremecedora. Así surge la vena pintoresca y burlona en la anécdota que confirma la importancia del caballo para el "paisano":

30 Véase $F, 77,191,201,208,294,76$, y I, 22. Los “indios" o "salvajes" eran en realidad un elemento socialmente muy distinto del habitante blanco de las campañas pastoras, el cual los consideraba enemigos declarados, destructores de sus poblaciones y de su riqueza ganadera. Otras obras literarias reflejan este estado de cosas (La cautiva de Echeverría, el Santos Vega de Ascasubi, y más tarde el Martín Fierro de Hernández). Sin embargo para Sarmiento, "indio" o "salvaje" se equiparan a "gaucho", como "desierto" a "pampa", en su papel de sinónimos de barbarie.

31 Véase $F, 43-46,66,68,69,76,100,170,193$.

32 Para el color local véase $F, 39 s s$, 66 y 73 , donde trae citas de Victor Hugo; 76 , donde compara las hordas beduinas y la montonera. Era observación casi obligada en la época la comparación del gaucho o del llanero con estos pueblos nómades, por intereses de tipo histórico o literario. 
El año 41 el Chacho, caudillo de los Llanos; emigró a Chile. - ¿Cómo le va, amigo? - le preguntaba uno. - iCómo me ha de ir! -contestó con el acento del dolor y de la melancolía. - ¡En Chile! iy a pie!! -Sólo un gaucho argentino sabe apreciar todas las desgracias y todas las angustias que estas dos frases expresan $(F, 66)$.

El espectáculo del potro indómito, del gaucho convertido en un centauro, entusiasma al escritor por sus contrastes de violencia, por la exaltación del valor y del primitivismo épico; en La campaña en el Ejército Grande nos describe esta escena cuyo número de actores multiplica el dinamismo y la tensión en el peligro:

Uno de los espectáculos más novedosos que se ofrecían a la vista era el de una división entera, montada en potros indómitos, y aquella doma de mil quinientos caballos, cayendo, levantando, haciendo piruetas en el aire o lanzándose a escape por los campos, hasta que, a la vuelta de dos horas de lucha, los brutos vencidos, la división recobraba su orden de marcha cual si fuera montada en caballos domesticados (XIV, 218-219).

El proceso de simbolización se cumple con el caballo. Aparece la mención del hecho real de que las caballadas de la montonera destruían los sembrados, obras de la cultura $(F, 224)$. También el estadio intermedio en el que predomina el valor simbólico aunque todavía conserva su adherencia a lo real, cuando alude al terror del que oía el tronar de las caballerías en la pampa. Su nota de grandeza y de siniestro augurio, anuncia el desencadenamiento de las fuerzas del mal, después del fusilamiento de Dorrego, y cierra el ciclo de devastación emprendido por Quiroga con una paz que es el reinado del vacío y de la muerte:

Desde este momento nada quedaba que hacer para los tímidos, sino taparse los oídos y cerrar los ojos. Los demás vuelan a las armas por todas partes y el tropel de los caballos hace retemblar la Pampa, y el cañón enseña su negra boca a la entrada de las ciudades $(F, 167)$.

El vencedor de la Ciudadela ha empujado fuera de los confines de la República los últimos sostenedores del sistema unitario. Las mechas de los cañones están apagadas, y las pisadas de los caballos han dejado de turbar el silencio de la Pampa $(F, 227)$.

Se da además el uso puramente metafórico, al representar la civilización y la barbarie con las plantas pisoteadas por sus cascos, fórmula corriente en la literatura europea que, referida al caballo de Atila, se había convertido en frase proverbial, pero que en el Facundo adquiere nueva vida por la confrontación con los hechos relatados ${ }^{\mathbf{3} 3}$.

${ }^{33}$ [Mendoza] "Con las disposiciones que yo le conozco a ese pueblo, en 


\section{El CUCHILlo}

El cuchillo es el otro elemento que Sarmiento destaca para caracterizar al gaucho, porque él le servirá para acentuar el aspecto sangriento de la tiranía. Su libro, que es un alegato contra el despotismo barbarizador en general y contra la particular forma del despotismo de Rosas, tenía que mostrarse fundamentalmente eficaz en el ataque, por eso pulsa la cuerda del asesinato desbordante en las manifestaciones brutales del degüello a cuchillo.

El comentario puede tomar aspecto objetivo: el uso del puñal es entonces un producto del medio y también de la herencia hispánica $^{34}$. La vida llena de peligros ha acostumbrado al gaucho a dar y recibir la muerte con estoicismo; carnear las reses, le ha habituado a no estremecerse ante la sangre derramada; el cuchillo es el instrumento de trabajo y el arma imprescindible. De este tipo de observaciones pasa insensiblemente a caracterizar el gobierno de Rosas como una forma retrógrada $\mathrm{y}$, en oposición a los gobiernos civilizados, destaca el uso de la cuchilla para ejercer la justicia, el degüello de los hombres al igual que el del ganado ${ }^{35}$.

Inicia su relato de la carrera de Facundo Quiroga con la ya famosa escena del tigre, en la que una anécdota adquiere el papel significativo del personaje y en la violenta muerte a puñaladas de la fiera descubre el carácter selvático del caudillo, su valor, su ferocidad, sus instintos de venganza desatada, asociados al animal que le sirvió de sobrenombre entre sus contemporáneos.

Varias veces más, lo presenta apuñalando a hombres en escenas de crueldad, de venganza o de simple turbulencia ${ }^{36}$. Una, especial-

dos años de un sistema semejante hubiérase vuelto un coloso; pero las pisadas de los caballos de Facundo vinieron luego a hollar estos retoños vigorosos de la civilización y el Frayle Aldao hizo pasar el arado y sembrar de sangre el suelo durante diez años. ¿Qué había de quedar!" (F, 20o); cf. también $F$, 201; I, 22, y otros pasajes en los que se nota la relación del bárbaro con los monumentos de la civilización que destruye: "Si La Rioja, como tenía doctores, hubiera tenido estatuas, éstas habrian servido para amarrar los caballos" ( $F$, 112); o éste de los Viajes, donde es clara la función simbólica: “... el gaucho que como aquellos antiguos hicsos en el Egipto, hase apoderado del gobierno de un pueblo culto, y paseado sus caballos y hecho sus hierras, sus festines y sus laceaduras en las plazas de las ciudades" $(\mathrm{V}, 61)$.

34 "El gaucho anda armado del cuchillo, que ha heredado de los españoles; esta peculiaridad de la Península, este grito característico de Zaragoza: iguerra a cuchillo!, es aquí más real que en España. El cuchillo, a más de una arma, es un instrumento que le sirve para todas sus ocupaciones: no puede vivir sin él, es como la trompa del elefante, su brazo, su mano, su dedo, su todo. EI gaucho, a la par de jinete, hace alarde de valiente, y el cuchillo brilla a cada momento, describiendo círculos en el aire, a la menor provocación, sin provocación alguna..." $(F, 67)$.

35 Véase $F, 77$ y 261.

36 Véase $F, 94,95,97$. 
mente, merece ser recordada por la capacidad de condensar en unas pocas líneas toda la vida del héroe y su repercusión en la destrucción de la civilización argentina:

Facundo, desertando de .Buenos Aires, se encamina a las provincias con tres compañeros. Una partida le da alcance; hace frente, libra una verdadera batalla, que permanece indecisa por algún tiempo, hasta que dando muerte a cuatro o cinco, puede continuar su camino, abriéndose paso todavía a puñaladas por entre otras partidas que hasta San Luis le salen al paso. Más tarde debía recorrer este mismo camino con un puñado de hombres, disolver ejércitos en lugar de partidas, e ir hasta la ciudadela famosa de Tucumán a borrar los últimos restos de la república y del orden civil $\left(F, 9^{6}\right)$.

Sarmiento ha reducido aquí la carrera de Quiroga a un viaje repetido a través del mismo camino, con el contraste de oscura vulgaridad al principio - huida de desertor, partidas que lo buscany de grandiosa proyección fatídica para la vida del país, al final -caudillo, ejércitos, cultura e instituciones-, y ha elegido a Tucumán, corazón de la República, cuna de su independencia, entre tantos combates que libró Quiroga, para conmover a los lectores con la resonancia de su nombre mancillado.

En los pasajes antes citados nos movemos en el terreno de los hechos, aunque elegidos, sin duda, por su poder caracterizador o simplemente para dar a la figura del caudillo un halo imaginativo lúgubre y violento. En ciertos casos, la referencia pasa insensiblemente del hecho a la función cuasi-metafórica: "Facundo, ignorante, bárbaro, que ha llevado por largos años una vida errante que sólo alumbran de vez en cuando los reflejos siniestros del puñal que gira en torno suyo..." $(F, 170)$.

Además, Sarmiento repite la actitud de clavar el cuchillo con valor puramente metafórico para referirse a la obra desintegradora de la tiranía: “. . .el Gobierno Central, Unitario, despótico, del estanciero D. Juan Manuel Rosas, que clava en la culta Buenos Aires el cuchillo del gaucho, y destruye la obra de los siglos, la civilización, las leyes y la libertad" $(F, 72)$.

El ganado, las ropas del gaucho, el color colorado, la sangre, y otros aspectos de la rusticidad, la crueldad o la simple destrucción, unidos a los ya estudiados, acabarían de configurar el cuadro de la barbarie en el Facundo. Por falta de espacio los dejaremos para otra ocasión, en la que lo completaremos oponiéndole también el mundo de la civilización tal como lo simboliza Sarmiento en las ciudades y en sus formas de vida.

Ana María Barrenechea

Instituto de Filología Hispánica de Buenos Aires

"Dr. Amado Alonso" 